(see page 695).

While there may be room for discussion, there are also the makings of a fight. Many academics or their champions, such as Gore, see in the Administration's words a threat to fundamenta inquiry. Gore told Inman "we don't want to even (sic) take the first step along the road that has made Soviet science so pitiful". Inman, on his side, complained that the press and some academics misrepresented his statements to mean that he wanted to "throw a net over the public". Yet some universities have already taken avoiding action. At Stanford University the Faculty Senate has approved a resolution urging the university to resist interference with free scientific communication.

Academics are highly sensitive to any threats to their independence and tend to cry foul when anyone suggests they submit to any authority whatever - be it university administrators trying to enforce government accounting rules or suggested self-censorship of militarily important research. Moreover, President Reagan's military build-up and talk of nuclear war is stirring antagonism at many US campuses, as the recent wave of teach-ins and meetings attests. It would be all too easy for these issues to be rolled into one ball of wax in many academics' minds: burdensome federal regulations, arms build-up, nuclear war and government controls to prevent espionage. The resulting feeling would be that the Administration is against the universities and does not understand them - a feeling reminiscent of some campus attitudes towards former Presidents Johnson and Nixon. Given its penchant for loose, inflammatory rhetoric on other matters, the Administration may find it too easy to characterize campus resistence to controls as unpatriotic. The push from the right would then shove the campuses left. If the Administration keeps to Inman's timetable, the universities will have to step briskly — and calmly and rationally — to avoid an open conflict .

\section{Big Brother's law}

The British Government seems indifferent to its electors' needs for protection from data banks.

The British Government has simply failed to understand why there is public anxiety that computerized records may be a threat to people's privacy and, thus, liberty. That is the most charitable reading of the white paper on the subject, now at last published.* A more cynical, but probably more accurate, interpretation is that the government is squarely out of sympathy with the fear that computerized data banks may infringe the rights of individuals for which reason it will continue to drag its feet on legislation, doing everything it can to ensure that the eventual law is the bare minimum necessary to comply with the Council of Europe Convention signed a year ago.

The grudging character of the government's intentions can be told from the only statement in the white paper of the reasons why legislation is necessary. This mean document correctly records that the Council of Europe convention will require its signatories not to transmit personal data files to countries without satisfactory legislation, notes that this restriction could be a threat to international companies operating in Britain as well as to British computer bureaux and therefore concludes that "in order to conform with international standards of privacy protection and to avoid possible barriers to trade", the government will introduce legislation that will "enable the United Kingdom to ratify the convention".

Shabbily, nowhere is there a flicker of acknowledgement that the protection of people's privacy is in itself desirable, a public good of the kind which governments are elected to cultivate. Indeed, the government's sense that it owes something to its electors is expressed only in the repeated promise that the cost of administering the promised legislation will be kept to a minimum, and will be no charge on public funds. Even the salaries of the proposed registrar of personal data banks and his staff will be recovered from the fees that must be paid by their operators. Individuals seeking to verify the accuracy of personal data on specific computer files will have to pay a fee "based on the principle that the costs for the demands are fully recovered". Those who, having paid their fees, think they have found their privacy to have been illegally infringed will have to mount prosecutions off their own bats, and at their own expense.

The government that happens historically to owe its existence to the Magna Carta, one of the earliest public declarations that tyranny is unacceptable to ordinary people, appears to be willing that ordinary people should take their chances in the courts if they have reason to believe that some injustice has been done by a data bank or those who operate it. Fortunately - this at least must be the hope - even the government's supporters in the House of Commons will be so affronted by what is now proposed that the unseemly legislation the government plans belatedly to introduce (not this year, perhaps not even next year) will be constructively and radically amended.

This is how libertarians in the House of Commons and elsewhere should argue. While computerized data banks are in principle no different from systems of records manually kept, they are potentially so much more efficient that their common use is tantamount to a qualititative change. So much has been acknowledged in the past decade by two government committees set up specifically to consider questions of privacy - the Younger committee (which reported in 1972) and the Lindop committee (reporting in 1978). False data, inadvertantly or even maliciously erroneous, can be damaging to those concerned. But even accurate data can be damaging, especially in the hands of those for whom they were not originally compiled. While it may be proper that information about people's dealings with tradespeople should be available to others in the same line of business, information such as this may be unwarrantably damaging in the hands of others, potential employers for example. Similarly, information about a person's medical history collected by one government department in the course of its legitimate business may be damaging when transferred to another.

So how should this transfer of data between different kinds of users be regulated? In its declaration of the principles on which the new legislation will be based, the British Government merely quotes the principles on which the European convention has been drawn (the chief of which is that a person should have access to any files about him, and the power to correct them if inaccurate or to erase them if illegally compiled). What needs to be decided, now and not later, is the basis on which the transfer of data may be allowed from one potlential user to another. It is simply not good enough to say that "it is expected that most applicants will be registered without question, but the Registrar will have power to make enquiries, to inspect data files and to require modifications to a system. In extreme cases, he may need to refuse registration...". What the government has so far failed to explain is how the registrar will decide which applications for registration are acceptable "without question".

The issue is especially important where the transfer of information between government departments is concerned. The European convention permits the exclusion from regulation of data banks "protecting state security, public safety, the monetary interests of the state or the suppression of criminal offences". This form of words is a sufficient licence for Big Brother. On the face of things, it will for example allow people's income-tax returns to be compared with their income from holdings of government securities or their applications for driving licenses to be checked against the records of the National Health Service, while the police will presumably be allowed to gather information from where they can in the cause of crime prevention. Are all these applications of data banks to be blithely sanctioned? By its repeated references to the European convention as the guiding principles on which the registrar will work, the British Government seems to intend just that. Parliament should insist that the European convention is not the final touchstone of what is permissible, but merely the starting point for what is bound to be a long and acrimonious argument.

*Data Protection, Cmnd 8539, 24pp. (HMSO, London, 1982) £2.30. 